\title{
A PROFILE: THE NEW PRESIDENT OF THE INTERNATIONAL MEDICAL SOCIETY OF PARAPLEGIA
}

\author{
Sir George Montario Bedbrook, Kt., O.B.E., Order of St John, \\ M.S.(Melb.), M.D.(Hon.W.A.), F.R.C.S., F.R.A.C.S., D.P.R.M.
}

Sir GeORGe BEDBROoKIgraduated from Melbourne University in 1944, and after several years of residency in that city, serving also as Lecturer in Anatomy to the University, culminated in achieving the Fellowship of the Royal Australasian College of Surgeons and the Master of Surgery of Melbourne University in I950.

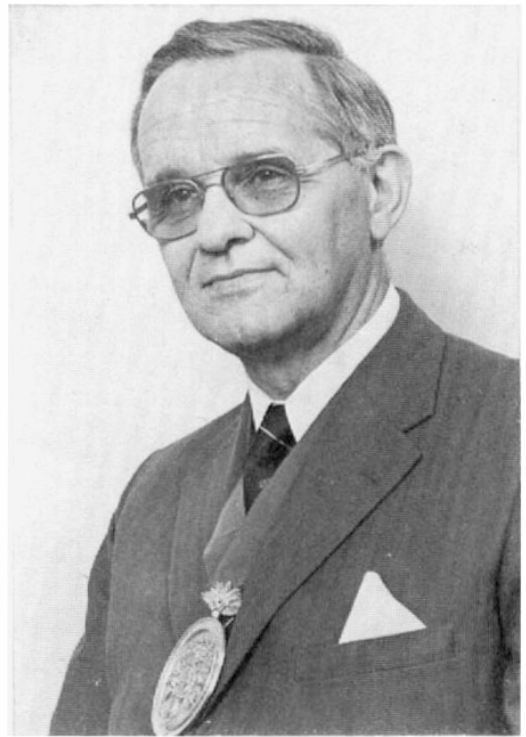

Sir George Bedbrook, O.B.E., O.St.J., M.S.(Melb.), M.D.(Hon.W.A.), F.R.C.S., F.R.A.C.S., D.P.R.M. wearing his chain of office as president of the Australian Orthopaedic Association.

Further years of postgraduate work followed in the United Kingdom, when Sir George made first contact with Sir Ludwig Guttmann and was introduced to the pioneer work being conducted at Stoke Mandeville Hospital.

His return to Australia was marked by the commencement of the Paraplegic Service at the Royal Perth Rehabilitation Hospital. Here the accommodation offered was initially an old transportable ward, but the quality of the service, which was the first comprehensive service in Australia for spinal cord injury, became rapidly acknowledged as outstanding.

Under Sir George's dynamic leadership the present modern centre was planned, and was finally erected in 1962. This year was also marked by the First Commonwealth Paraplegic Games being held in Perth under his direction.

The development of the Paraplegic Association of Western Australia followed, 
and in 1969 the Quadriplegic Centre was opened and now provides accommodation for 90 residents and employment for 260 disabled people with ailments of a multi-disciplinary nature, who though not employable in normal commerce or industry, are producing an annual output approaching two million dollars (Australian) under sheltered workshop conditions.

The Spinal Unit in Perth is now acknowledged as an outstanding centre for postgraduate study and training in spinal cord injuries. Most of the spinal centres in Australia are led by physicians who have received part of their training in Perth, and this applied also to other centres as far afield as New Zealand, Japan, India, the Philippines, Taiwan and Indonesia.

Sir George is an inveterate traveller and lecturer in many countries throughout the world to promote the modern concept of treatment of spinal cord injuries, with special emphasis upon rehabilitation and integration into the community. His publications now number more than 50, and the recent authoritative book on The total care of Paraplegia under his editorship, should be required reading for those clinicians working in this field or preparing to do so.

His energy and dynamic leadership, both nationally and internationally, have been recognised by the award of the Order of the British Empire in 1963 and a well-deserved knighthood from Her Majesty the Queen in I978.

Sir George's work over the past 27 years has been of very great service to those with the severe disability of spinal cord injury. In 1972, he resigned as Head of the Department of Paraplegia, to continue as Head of the Department of Orthopaedic Surgery in Perth, Australia, and from I975 until I979 was chairman of this Department. He continues as Senior Surgeon.

This year he is State Chairman for the Committee for the International Year of Disabled Persons.

Sir George is a Past President of the Australian Orthopaedic Association.

At home he is a very private and domestic person, proud of his five children and seven grandchildren.

His friendship and loyalty as a colleague are something to be greatly valued. His present election as President of the International Medical Society of Paraplegia will ensure that this Society will go on developing as the internationally recognised forum for clinicians throughout the world to exchange new ideas and develop modern trends in the treatment of the spinal disabled.

E. R. GRIFFITHS

Head of Spinal Department, Royal Perth (Rehabilitation) Hospital, Perth, Western Australia. 